\title{
Rheumatoid arthritis bone marrow environment supports Th17 response
}

\author{
Ewa Kuca-Warnawin ${ }^{1 *}$, Weronika Kurowska', Monika Prochorec-Sobieszek ${ }^{2,3}$, Anna Radzikowska', \\ Tomasz Burakowski', Urszula Skalska', Magdalena Massalska', Magdalena Plebańczyk', \\ Barbara Małdyk-Nowakowska ${ }^{4}$, Iwona Słowińska ${ }^{4}$, Robert Gasik ${ }^{4}$ and Włodzimierz Maśliński ${ }^{1}$
}

\begin{abstract}
Background: Rheumatoid arthritis (RA) is a systemic, autoimmune disease leading to joint destruction and ultimately disability. Bone marrow (BM) is an important compartment in RA, where pathological processes from "outside the joint" can occur. IL-17 is a cytokine that exerts proinflammatory effects and participates in the process of bone destruction. It is believed that IL-17 is involved in pathogenesis of RA. However, little is known about the biology of this cytokine in BM. In the present study we investigated Th17-related cytokines in RA BM.

Methods: BM samples were obtained from RA and osteoarthritis $(\mathrm{OA})$ patients during total hip replacement surgery. Levels of IL-17AF, IL-17AA, IL-17FF, IL-1 $\beta$, IL-6, IL-23, TGF- $\beta$ and CCL20 in BM plasma were determined by specific enzyme-linked immunosorbent assay tests. Percentage of IL-17-producing cells in BM was evaluated by flow cytometry. The effect of IL-15 stimulation on IL-17 production by BM mononuclear cells was examined in vitro.

Results: Increased levels of IL-17AF were observed in BM plasma of RA patients in comparison to OA patients. Increased concentrations of IL-1 $\beta$, IL-6 and CCL20 were observed in RA compared to OA BM plasma. Concordant with these findings, significantly increased percentages of $\mathrm{CD}^{+} \mathrm{CD} 4^{+} \mathrm{IL}-17^{+}$and $\mathrm{CD} 3^{+} \mathrm{CD} 4^{+} \mathrm{IL}-17^{+} \mathrm{IFN}-\gamma^{+}$cells were present in RA BM in comparison to OA BM samples. Finally, abundant in RA BM, IL-15 increased IL-17 production by cultured BM mononuclear cells.
\end{abstract}

Conclusions: In the course of RA, the BM microenvironment can promote the development of Th17 cell responses and overproduction of IL-17AF that may lead to increased inflammation and tissue destruction in RA BM.

Keywords: Bone marrow, IL-17, IL-15, CCL20, Rheumatoid arthritis

\section{Background}

Rheumatoid arthritis (RA) is a systemic, autoimmune disease leading to joint destruction and ultimately disability [1]. Data obtained in the last decade indicate that bone marrow $(\mathrm{BM})$ is an important compartment in RA, where pathological processes from "outside the joint" can occur. The cellular infiltrates found in RA BM consist of immunological cells that may form aggregates resembling germinal centres in secondary lymphoid organs [2]. Our previous flow cytometry analyses showed an increased number of mononuclear cells and

\footnotetext{
* Correspondence: ewa.kuca-warnawin@spartanska.pl

${ }^{1}$ Department of Pathophysiology and Immunology, National Institute of Geriatrics, Rheumatology and Rehabilitation (NIGRR), Spartanska 1, 02-637 Warsaw, Poland

Full list of author information is available at the end of the article
}

accumulation of activated $\mathrm{T}$ cells and $\mathrm{B}$ cells in the BM of RA patients in comparison to osteoarthritis (OA) patients [2, 3]. Increased levels of proinflammatory cytokines and chemokines in RA BM were also observed, indicating an ongoing inflammatory process in this compartment. One of these cytokines is IL-15, which can be involved in T-cell activation [2, 4-6].

Interleukin-17 is predominantly expressed by a specific subset of human T-helper cells-Th17 cells. In addition, recent evidence indicates that IL-17 could also be produced by several innate immune cells and activated or inflammatory $\mathrm{T}$ cells [7]. It is assumed that this cytokine overproduction plays a crucial role in inflammation and the development of several autoimmune diseases, including RA. However, little is known about biology of this cytokine in BM. There are six known isoforms of 
IL-17 (IL-17A-IL-17 F). Th17 cells are able to produce only proinflammatory IL-17A and IL-17 F, where IL-17A is considered more potent than IL-17 F. These two isoforms create dimers: in body fluids, homodimers IL-17AA and IL-17FF and also heterodimer IL-17AF could be detected [8]. Differentiation of human naïve $\mathrm{T}$ cells into Th17 cells requires the presence of TGF- $\beta$ and at least one of the following proinflammatory cytokines: IL-1 $\beta$, IL-6, IL-21 and IL-23 $[9,10]$. In turn, Th1-related cytokine IFN- $\gamma$ and Th2-related IL-4 suppress differentiation of Th17 cells $[11,12]$. The proinflammatory cytokine IL-15 may also be involved in IL-17 production. Concentrations of IL-17 were demonstrated previously to correlate with concentrations of IL-15 in both serum and synovial fluid of RA patients [13]. Macrophage inflammatory protein-3 $\alpha$ (MIP-3 $\alpha /$ CCL20) has been reported to preferentially attract Th17 cells (via CCR6 binding) to the inflamed rheumatoid joints and the small intestine $[14,15]$.

In the present study we hypothesized that the RA BM microenvironment supports the development of Th17 cells and Th17 cell response. To verify this hypothesis, we examined the frequency of Th1, Th2 and Th17 cell populations as well as the concentrations of cytokines involved in Th17 cell differentiation and migration in $\mathrm{BM}$ from RA and OA patients. We analysed the concentrations of IL-17AA, IL-17AF and IL-17FF in the BM plasma and peripheral blood plasma of RA and OA patients. Moreover, because of the potential stimulatory effect of IL-15, the impact of this cytokine on IL-17 production has also been evaluated in vitro.

\section{Methods}

\section{Patients}

$\mathrm{BM}$ and peripheral blood were obtained from patients with RA and from patients with OA diagnosed according to American College of Rheumatology revised criteria for RA or for OA $[16,17]$. Peripheral blood and BM samples were obtained from patients undergoing total hip replacement surgery. Patients' demographic and clinical characteristics are summarized in Table 1.

\section{Immunohistochemistry}

Bone marrow samples obtained from six OA patients and six RA patients were examined histopathologically. BM samples were fixed in Oxford fixative (formaldehyde $40 \%$, glacial acetic acid $2 \%$, sodium chloride $8.7 \%$, distilled water), routinely processed and embedded in paraffin wax. Sections $3 \mu \mathrm{m}$ thick were cut and stained with haematoxylin and eosin. The following antibodies were then used for further staining: anti-CD8 (polyclonal Ab, dilution 1:50; Dako, Glostrup, Denmark), anti-CD4 (clone 4B12, dilution 1:10; Novocastra, now part of Leica Microsystems, Wetzlar, Germany) and anti-IL-17A
Table 1 Patients' demographic and clinical characteristics

\begin{tabular}{lll}
\hline & RA $(n=67)$ & OA $(n=43)$ \\
\hline $\begin{array}{l}\text { Age, median } \\
\text { (minimum-maximum) }\end{array}$ & $58(31-69)$ & $59(30-69)$ \\
Sex, female/male & $54 / 15$ & $42 / 21$ \\
$\begin{array}{l}\text { ESR (mm/h), median } \\
\text { (minimum-maximum) }\end{array}$ & $37(5-91)$ & $11(2-38)$ \\
$\begin{array}{l}\text { CRP (mg/l), median } \\
\text { (minimum-maximum) }\end{array}$ & $21(0-74)$ & $3(0-28)$ \\
Methotrexate & 40 & 0 \\
Steroids & 54 & 0 \\
Biologics & 0 & 0 \\
\hline
\end{tabular}

CRP C-reactive protein, ESR erythrocyte sedimentation rate, $O A$ osteoarthritis, $R A$ rheumatoid arthritis

(dilution 1:50; Santa Cruz). Staining was performed according to the manufacturer's instructions. The EnVision Detection System (Dako Denmark A/S, Glostrup, Denmark) was used for detection. Positive controls were performed on human tonsils. Negative (isotype) controls were performed using ready-to-use FLEX Negative Control Mouse (cocktail of murine IgG1, IgG2a, IgG2b, IgG3 and IgM, code number IR750; Dako Denmark A/ S). Samples were reviewed for expression of these proteins by a qualified histopathologist who was blinded to outcome. Appropriate cellular localization for immunostaining was membrane for CD8 and CD4 and cytoplasmatic for IL-17A. All photographs were taken using Olympus microscope cameras: DP72 Olympus BX63 and DP12 Olympus BX (Olympus, Tokyo, Japan).

\section{BM plasma concentration of cytokines}

Bone marrow plasma samples were obtained as we described previously $[2,4]$. Concentrations of tested cytokines IL-17AA, IL-17AF, IL-17FF, IL-17A, TGF- $\beta$, IL-23, IL-1 $\beta$, TNF- $\alpha$, IL-4, IFN- $\gamma$, IL-6, CCL20 and IL-15 were detected using specific enzyme-linked immunosorbent assays (ELISAs). All measurements were performed in duplicate.

Concentrations of homodimer IL-17AA, homodimer IL-17FF and heterodimer IL-17AF were analysed by respective ELISA Ready-SET-Go kits (eBioscience, San Diego, CA, USA) according to the manufacturer's instructions. The detection limits were $4 \mathrm{pg} / \mathrm{ml}$ for IL$17 \mathrm{AA}, 16 \mathrm{pg} / \mathrm{ml}$ for IL-17FF and $30 \mathrm{pg} / \mathrm{ml}$ for IL-17AF.

Concentrations of TGF- $\beta$, IL-15, IL-1 $\beta$ and CCL20 were measured by respective ELISA Duo Set test (R\&D Systems, Minneapolis, MN, USA) according to the manufacturer's instructions. The detection limits were $31 \mathrm{pg} /$ $\mathrm{ml}$ for TGB- $\beta, 3.9 \mathrm{pg} / \mathrm{ml}$ for IL- $1 \beta$ and $15.6 \mathrm{pg} / \mathrm{ml}$ for CCL20 and IL-15.

The concentration of IL-23 was assessed using polyclonal rat IgG anti-IL-23p19 as a coating $\mathrm{Ab}$ and biotinylated mouse IgG anti-IL-23 p40/70 as a detecting Ab 
(both Abs from Nautec, eBiosciences, San Diego, CA, USA). After staining with detecting antibody, samples were incubated with streptavidin conjugated with horseradish peroxidase (Sigma). Recombinant human IL-23 (R\&D Systems) was used as a standard. The peroxidase reaction was developed using $o$-phenylenediamine dihydrochloride (Sigma). The optical density was measured at $492 \mathrm{~nm}$ with an automatic ELISA reader. The detection limit was $15 \mathrm{pg} / \mathrm{ml}$.

Concentrations of IL-6 were analysed as described previously [18].

\section{Isolation, culture and IL-15 stimulation of BM mononuclear cells}

Bone marrow mononuclear cells (BMMC) were isolated by density gradient centrifugation using Ficoll-Paque (GE Healthcare Bio-Sciences, Uppsala, Sweden). Cells $\left(2 \times 10^{6} / \mathrm{ml}\right)$ were cultured in 24-well plates (Nunc, Roskilde, Denmark) in RPMI 1640 medium (Invitrogen, Paisley, UK) supplemented with $2 \mathrm{mML}$-glutamine (Invitrogen), 10\% heat-inactivated fetal calf serum (FCS) (Biochrom AG, Berlin, Germany), $100 \mathrm{U} / \mathrm{ml}$ penicillin, $100 \mu \mathrm{g} / \mathrm{ml}$ streptomycin (both antibiotics from Polfa Tarchomin, Warsaw, Poland), $30 \mu \mathrm{g} / \mathrm{ml}$ kanamycin (Sigma, St Louis, MO, USA) and 1 mM HEPES (Invitrogen) for 24 hours. For IL-15 stimulation, BMMC were cultured for an additional 72 hours in the presence of IL-15 (25 ng/ml) (R\&D Systems).

\section{Flow cytometry evaluation of IL-15 receptor complex expression on $\mathrm{CD}^{+}{ }^{+} \mathrm{CD} 4^{+}$cells}

To estimate the surface expression of IL-15R receptor complex (CD122, CD132, CD215), BMMC were washed first in PBS (without $\mathrm{Mg}^{2+} / \mathrm{Ca}^{2+}$ ) buffer containing $1 \%$ BSA and $0.06 \% \mathrm{NaN}_{3}$, and then with glycine buffer (0.1 M, pH 3.0). In the next step BMMC were stained with antibodies anti-CD3-APC-Cy7, anti-CD4-PeCy7 (Becton Dickinson, San Diego, CA, USA), anti-CD122-FITC, anti-CD132-APC and anti-CD215-PE (R\&D Systems). After the washing step, cells were incubated with 7-AAD to stain and exclude dead cells. Cells were acquired and analysed using FACSAria and Diva software (BD).

\section{Measurement of secretory and intracellular IL-17 production upon IL-15 stimulation}

Supernatants from BMMC cultured with or without IL-15 were collected for secretory IL-17A concentration measurement using Quantikine ELISA (R\&D Systems) according to the manufacturer's instructions. Supernatants from unstimulated cell cultures served as control. In experiments designed for intracellular staining, BMMC were treated with PMA, ionomycin and GolgiStop 6 hours before the end of the culture. After staining of respective membrane antigens using anti-CD3 APC,
anti-CD4 FITC and anti-CD8 APC-Cy7 Abs, cells were fixed and permeabilized. The cells were then stained for intracellular expression of IL-17A using anti-IL-17A Ab conjugated with PE. Washed cells were acquired and analysed using FACSAria and Diva software (BD).

\section{Flow cytometry evaluation of Th1/Th2/Th17 cell subsets in $\mathrm{BM}$}

Freshly isolated BMMC from patients' BM samples were treated for 6 hours with PMA $(50 \mathrm{ng} / \mathrm{ml})$ and ionomycin $(1 \mu \mathrm{g} / \mathrm{ml})$ in the presence of GolgiStop protein transport inhibitor. The cells were then harvested and stained for respective membrane antigens using anti-CD3 PerCpCy5.5, anti-CD4 Pe-Cy7 and anti-CD8 APC-Cy7 murine Abs. In the next step, cells were fixed and permeabilized using BD Cytofix/Cytoperm kit. Subsequently, intracellular staining using anti-IL-17A-PE, anti-IFN- $\gamma$-FITC and IL-4-APC Abs were performed. After the washing step, cells were acquired and analysed using a FACSAria cell sorter/cytometer and Diva software. All used reagents were purchased from Becton Dickinson (San Jose, CA, USA).

\section{Statistical analysis}

Data were analysed using GraphPad Prism 6 software. As obtained data were not normally distributed, according to the D'Agostino-Pearson omnibus normality test and the Shapiro-Wilk normality test, non-parametric tests were used for estimation of statistical significance of results. Comparisons between RA and OA were analysed by two-tailed Mann-Whitney $U$ test. Correlations between the concentrations of cytokines were assessed using the Spearman test. The differences in IL-17 production after IL-15 stimulation were tested for statistical significance using the Wilcoxon test. $p<0.05$ was considered statistically significant. Data are shown in the text as the median. Data are shown in the figures as the median with interquartile range or dots representing individual results.

\section{Results}

IL-17-positive cells are present in BM of RA patients

Immunohistopathological examination showed the presence of IL-17A-positive cells in BM samples obtained both from RA and OA patients (Fig. 1a-f). In immunohistochemical experiments we used an antibody against IL-17A monomer. We consider that positive staining with this antibody reflects the presence of both IL-17AA and IL-17AF dimers. Importantly, using ELISA, we found statistically significantly higher concentration of IL-17AF heterodimer in BM plasma of patients with RA (126.6 pg/ $\mathrm{ml}, n=28)$ compared to OA $(92.96 \mathrm{pg} / \mathrm{ml}, n=32)$ (Fig. $1 \mathrm{~g}$ ), indicating enhanced secretion of IL-17AF in RA BM. It is noteworthy that in both groups of patients the 

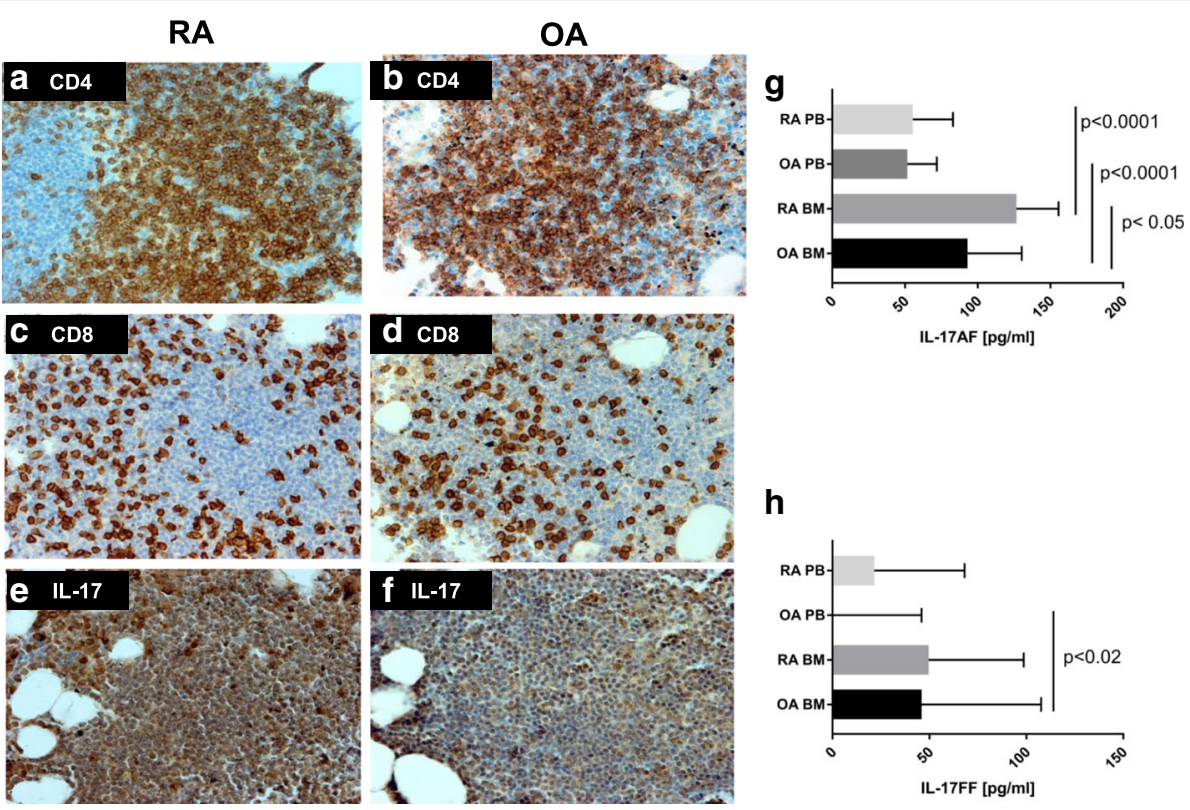

Fig. 1 a-f Immunohistochemical staining of BM samples obtained from patients with RA $(n=6)$ and OA $(n=6)$; EnVision stain, $\times 200$. a, b CD4 ${ }^{+}$ $\mathrm{T}$ cells in lymphoid follicle. $\mathbf{c}, \mathbf{d} C D 8^{+} \mathrm{T}$ cells in lymphoid follicle. $\mathbf{e}, \mathbf{f} \| \mathrm{L}-17 \mathrm{~A}$ expression in lymphocytes in lymphoid follicle. $\mathbf{g}$ Concentration of IL-17AF in OA and RA BM plasma (OA $n=32 ; \mathrm{RA} n=28)$ and in OA and RA blood plasma (OA $n=21 ; \mathrm{RA} n=15)$. $\mathbf{h}$ Concentration of IL-17FF in $\mathrm{OA}$ and RA BM plasma (OA $n=34 ; \mathrm{RA} n=28)$ and in OA and RA blood plasma (OA $n=23 ; \mathrm{RA} n=15)$. Differences between groups were calculated using Mann-Whitney $U$ test. BM bone marrow, IL interleukin, OA osteoarthritis, PB peripheral blood, RA rheumatoid arthritis

concentration of IL-17AF heterodimer was higher in BM plasma than in peripheral blood plasma. Surprisingly, there were no differences in IL-17FF homodimer concentration between $\mathrm{OA}$ BM $(45.98 \mathrm{pg} / \mathrm{ml})$ and $\mathrm{RA} \mathrm{BM}$ $(49.59 \mathrm{pg} / \mathrm{ml})$ (Fig. 1h). The IL-17AA homodimer was detected only in 3 of $32 \mathrm{OA}$ samples and 2 of 28 RA samples (data not shown). These results support other authors' observations that IL-17A exists mainly as an IL-17AF heterodimer [19]. Since on the basis of our experiments IL-17AA is hardly detectable in RA and OA BM plasma and IL-17FF levels are similar in both groups of patients, in the next flow cytometry experiments only intracellular expression of IL-17A was studied and positively stained cells were considered as the cells producing IL-17AF heterodimer.

\section{Frequency of IL-17-positive cells is increased in RA BM}

The percentage of $\mathrm{CD}^{+} \mathrm{CD} 4^{+} \mathrm{IL}-17^{+}$cells was significantly higher in $\mathrm{BM}$ of RA patients in comparison to OA patients $(1.0 \%$ vs $0.6 \%, p<0.001)$ (Fig. $2 b)$. Similarly, the percentage of $\mathrm{CD}^{+} \mathrm{CD} 4^{+} \mathrm{IL}-17^{+} \mathrm{IFN}-\gamma^{+}$cells was higher in $\mathrm{BM}$ of RA patients in comparison to $\mathrm{BM}$ of OA patients $(0.2 \%$ vs $0.1 \%, p<0.03)$ (Fig. 2 c). Both differences were statistically significant. We did not observe significant differences in $\mathrm{BM}$ percentage of $\mathrm{CD}^{+} \mathrm{CD} 4$ ${ }^{+} \mathrm{IL}_{-} 4^{+}(4.0 \%$ vs $3.1 \%)$ and $\mathrm{CD}^{+} \mathrm{CD} 4{ }^{+} \mathrm{IFN}-\gamma^{+}(12.9 \%$ vs 7.65\%) between RA and OA patients (Fig. 2d, e).
Increased frequency of $\mathrm{CD} 3^{+} \mathrm{CD} 4^{+} \mathrm{IL}-17^{+}$cells in RA BM suggests the recruitment of Th17 cells from the periphery or Th17 cell differentiation/stimulation in situ. Our next experiments were performed in order to test these two possibilities.

\section{Proinflammatory milieu of RA BM microenvironment}

In the next step the concentrations of cytokines involved in human Th17 cell differentiation were investigated in BM patient samples. We found an increased concentration of IL-6 $(1105 \mathrm{pg} / \mathrm{ml}$ vs $198 \mathrm{pg} / \mathrm{ml}, p<0.05)$ and IL$1 \beta(2589 \mathrm{pg} / \mathrm{ml}$ vs $354 \mathrm{pg} / \mathrm{ml}, p<0.01)$ in $\mathrm{RA} \mathrm{BM}$ plasma in comparison to OA BM plasma (Fig. 3a, b). However, the differences in IL-23 $(981 \mathrm{pg} / \mathrm{ml}$ vs $2034 \mathrm{pg} / \mathrm{ml}$ ) and TGF- $\beta$ (18.9 $\mathrm{pg} / \mathrm{ml}$ vs $24.3 \mathrm{pg} / \mathrm{ml})$ concentrations in both groups of patients were not statistically significant (Fig. 3c, d). Concentrations of Th1-related cytokine IFN- $\gamma(46 \mathrm{pg} / \mathrm{ml}$ vs $68 \mathrm{pg} / \mathrm{ml})$ and Th2-related IL-4 ( $2.6 \mathrm{pg} / \mathrm{ml}$ vs $3.2 \mathrm{pg} / \mathrm{ml})$ were similar in both groups of patients (Fig. 3e, f). In addition, we found an increased concentration of TNF- $\alpha$, an important player in the proinflammatory cytokine network, in RA BM plasma in comparison to OA BM plasma $(966.7 \mathrm{pg} / \mathrm{ml}$ vs $435.5 \mathrm{pg} / \mathrm{ml}, p<0.05$ ) (Fig. 3g). An important chemokine that attracts Th17 cells by binding to receptor CCR6 is CCL20. CCR6 is also a known marker of Th17 cells [20]. Interestingly, we found increased concentration of CCL20 chemokine in RA BM (median value $46.7 \mathrm{pg} / \mathrm{ml}$ ) in 

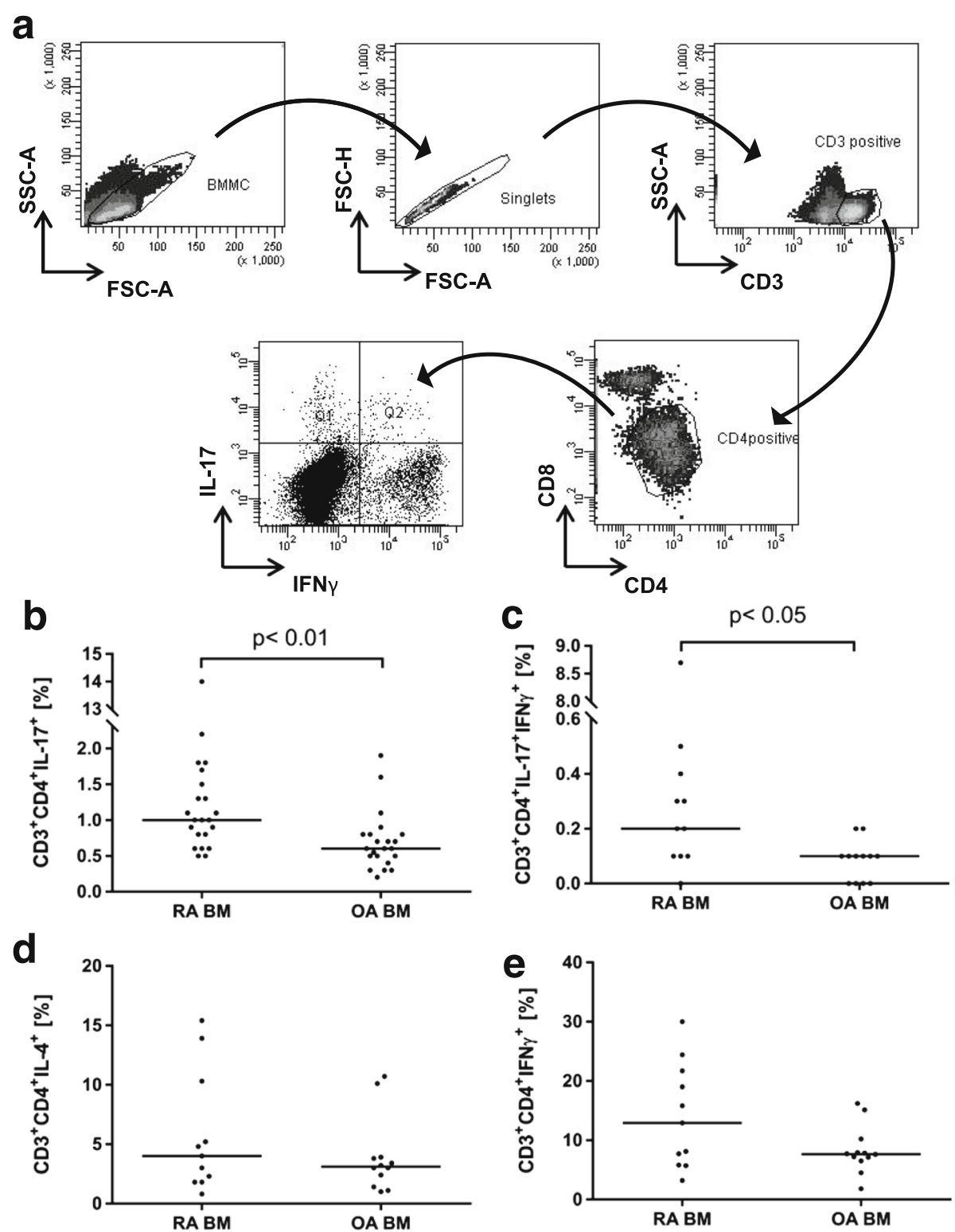

Fig. 2 Flow cytometry analysis of Th1, Th2 and Th17 lymphocyte subpopulations in OA and RA BM. a Representative gating strategy for FACS of RA $B M M C$, showing $\mathrm{CD}^{+} \mathrm{CD}^{+}$lymphocytes with intracellular staining for IL-17 and IFN- $\gamma$ after PMA/ionomycin stimulation. $\mathbf{b}$ Percentage of $\mathrm{CD} 3^{+} \mathrm{CD} 4$ ${ }^{+} \mathrm{IL}-17 \mathrm{~A}^{+}$cells $(\mathrm{OA} n=22 ; \mathrm{RA} n=22)$ c Percentage of $\mathrm{CD}^{+} \mathrm{CD}^{+} \mathrm{IL}-17 \mathrm{~A}^{+} \mathrm{IFN}-\gamma^{+}$cells $(\mathrm{OA} n=12 ; \mathrm{RA} n=11)$. $\mathbf{d}$ Percentage of $\mathrm{CD} 3^{+} \mathrm{CD} 4^{+} \mathrm{IL}-4^{+}$cells $(\mathrm{OA}$ $n=12$; RA $n=11)$. e Percentage of $\mathrm{CD}^{+} \mathrm{CD}^{+} \mathrm{IFN}-\gamma^{+}$cells $(\mathrm{OA} n=12$; RA $n=11)$. Differences between groups were calculated using Mann-Whitney $U$ test. BM bone marrow, BMMC bone marrow mononuclear cells, FSC forward scatter, IFN interferon, IL interleukin, OA osteoarthritis, RA rheumatoid arthritis, SSC side scatter

comparison to OA BM (median value $0 \mathrm{pg} / \mathrm{ml}$ ) (Fig. 3h), which could be responsible for the increased number of Th17 cells in RA BM.

\section{IL-15 increases IL-17 secretion by RA BMMC}

Our previous data indicate that IL-15 concentration is elevated in RA BM [2]. It was also shown that IL-15 levels correlate with IL-17 levels in sera of RA patients [13]. Our present data show that IL-15 concentration correlated with IL-17AF concentration in RA BM but did not correlate with IL-17FF concentration (Table 2).

In the next step we investigated the impact of IL-15 stimulation on IL-17 production by BMMC. Although in both groups of patients we observed a statistically significant increase in IL-17A secretion after stimulation with IL-15 (Fig. 4a), such an effect was more profound in BMMC derived from the RA patient group. 

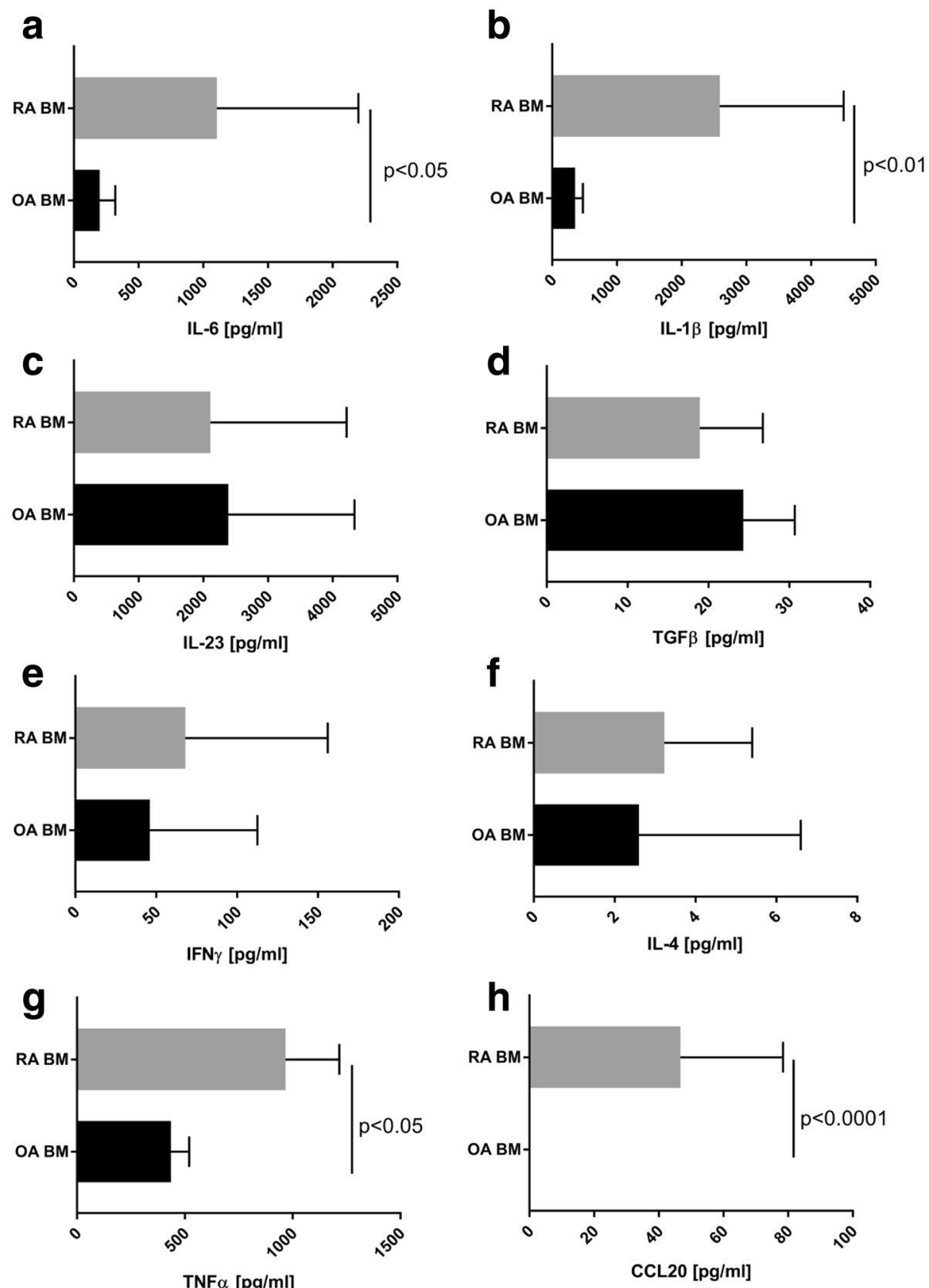

Fig. 3 Concentrations of selected cytokines associated with Th17 cell differentiation and activity in BM plasma of RA and OA patients. All cytokine concentrations detected using specific ELISAs. a-d Concentration of IL-6, IL-1 $\beta$, IL-23 and TGF- $\beta$ (OA $n=13-15 ;$ RA $n=10-14)$. e, $\mathbf{f}$ Concentrations of IFN- $\gamma$ and IL-4 (OA $n=28-29 ;$ RA $n=27)$. $\mathbf{g}$ Concentration of TNF-a (OA $n=14 ;$ RA $n=12)$. $\mathbf{h}$ Concentration of CCL20 (OA $n=35$; RA $n=28)$. Differences between groups were calculated using Mann-Whitney $U$ test. BM bone marrow, IFN interferon, IL interleukin, OA osteoarthritis, RA rheumatoid arthritis, TGF transforming growth factor, TNF tumour necrosis factor

Table 2 Correlation coefficients $(r)$ and significance values $(p)$ between levels of IL-17AF, IL-17FF and IL-15 in BM plasma of RA patients $(n=28)$

\begin{tabular}{llll}
\hline & & $r$ & $p$ \\
\hline RA BM IL-17AF & RA BM IL-15 & 0.38 & $<0.05$ \\
RA BM IL-17FF & RA BM IL-15 & 0.034 & ns \\
\hline
\end{tabular}

$B M$ bone marrow, IL interleukin, $n s$ not significant, $R A$ rheumatoid arthritis

\section{IL-15 does not influence Th17 differentiation}

The next experiments were designed to clarify whether IL-15 stimulation influences Th17 cell differentiation. BMMC derived from RA and OA were stimulated for 72 hours with IL-15 and at the end of culture the percentage of IL-17A-positive cells was measured by flow cytometry. In RA patients as well as in OA patients, 
a

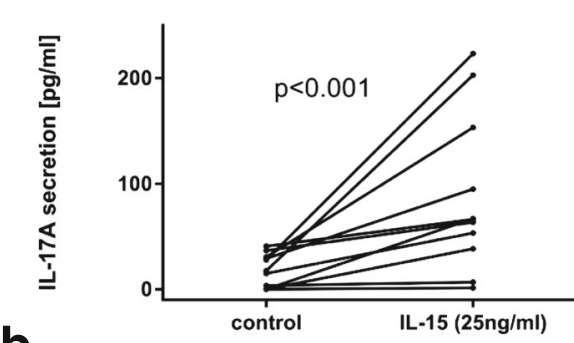

b
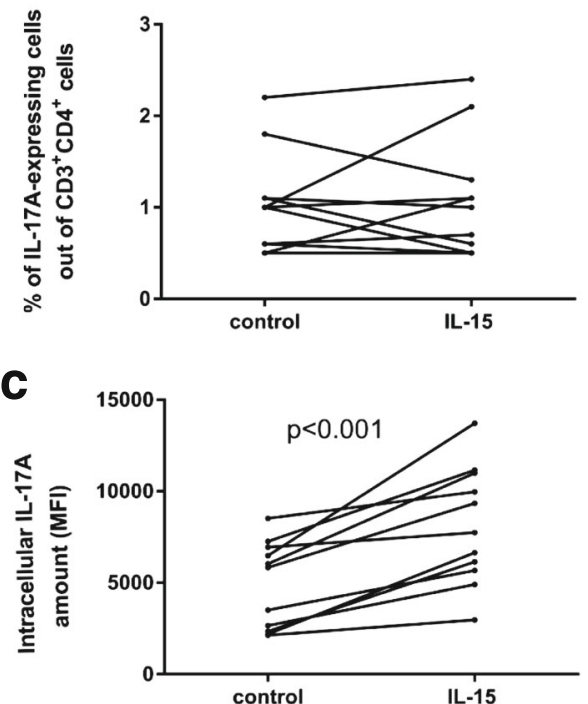

OA
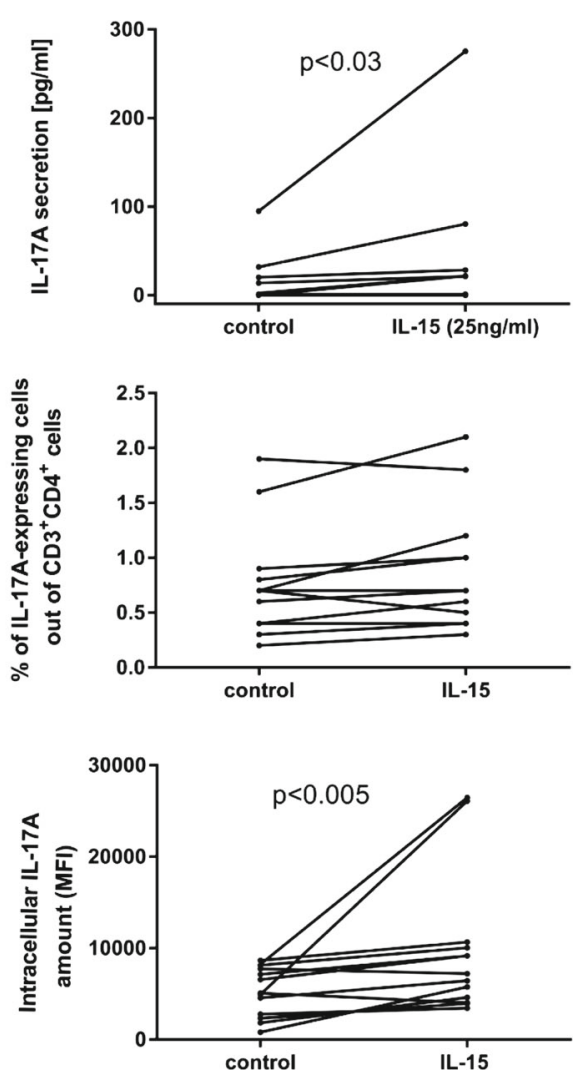

Fig. 4 Impact of IL-15 stimulation on IL-17 production and on Th17 differentiation. BMMC from OA (right panel) and RA (left panel) patients cultured for 72 hours without (control) or with addition of $1 \mathrm{~L}-15$ ( $25 \mathrm{ng} / \mathrm{ml})$. At the end of cell culture, supernatants were collected for ELISA (a) and cells were designated for FACS analysis (b, c). a Concentration of secreted IL-17A in cell culture supernatants (RA $n=11 ; \mathrm{OA} n=11$ ). $\mathbf{b}$ Percentage of IL-17A-expressing CD $3^{+} \mathrm{CD} 4^{+}$ cells out of total $\mathrm{CD}^{+} \mathrm{CD}^{+}$cells (RA $\left.n=11 ; \mathrm{OA} n=13\right)$.c Intracellular amount of IL-17A (reflected by MFI) in $\mathrm{CD}^{+} \mathrm{CD}^{+}$cells $(\mathrm{RA} n=11$; OA $n=13)$. IL interleukin, MFI mean fluorescence intensity, OA osteoarthritis, RA rheumatoid arthritis

stimulation with IL-15 did not increase the percentage of IL-17A-producing cells in the culture, suggesting the lack of IL-15 impact on Th17 differentiation (Fig. 4b). However, in both groups of patients an increased intracellular production of IL-17A (mean fluorescence intensity value (MFI)) in $\mathrm{CD}^{+} \mathrm{CD}^{+}$cells was noted upon IL-15 stimulation (Fig. 4c). These results suggest that IL-15 stimulation enhances IL-17A production in existing/already differentiated Th17 cells.

\section{IL-15 receptor complex is present on $\mathrm{CD}^{+} \mathrm{CD}^{+}$cells isolated from bone marrow}

The heterotrimeric IL-15 receptor complex consists of a unique IL-15R $\alpha$ subunit (CD215), IL-2/IL-15R $\beta$ (CD122) and the common gamma-chain/IL-15R $\gamma$ subunit (CD132). IL-15 binds with high affinity to IL-15R $\alpha$ (Kd $=10-11 \mathrm{M})$. IL-15/IL-15R $\alpha$ then associates with a complex composed of the IL-2/IL-15R $\beta$ and common gamma-chain/IL-15R $\gamma$ subunits, expressed either on the same cell (cis presentation) or on a different cell (trans presentation). In some experimental models, IL-15 bound to the IL-15R $\alpha$ acts much more efficiently than soluble IL-15. We found that the percentage of CD3 ${ }^{+} \mathrm{CD} 4{ }^{+} \mathrm{CD} 215^{+}$cells was similar in BM of RA patients in comparison to OA patients (1.6\% vs $1.9 \%$, ns) (Fig. 5a). Also, the percentage of $\mathrm{CD} 3^{+} \mathrm{CD} 4^{+} \mathrm{CD} 122^{+}$cells was similar in BM of RA and OA patients $(6.5 \%$ vs $5.2 \%$, ns) (Fig. 5b). In addition, we did not observe any differences in MFI value of CD215 and CD122 on $\mathrm{CD}^{+}{ }^{+} \mathrm{CD} 4^{+}$cells in both studied patients groups (Fig. 5d, e). However, we noted a significantly higher percentage of $\mathrm{CD}^{+}{ }^{+} \mathrm{CD} 4^{+} \mathrm{CD} 132^{+}$cells in $\mathrm{RA} \mathrm{BM}$ in comparison to OA BM $(18.7 \%$ vs $8.9 \%, p<0.005)$ (Fig. 5c). Furthermore, MFI value of CD132 on CD3 ${ }^{+} \mathrm{CD} 4{ }^{+} \mathrm{CD} 132^{+}$cells obtained from RA BM was found to be higher in comparison to the same type of cells obtained from OA BM (625 vs 458, $p<0.05)$ (Fig. 5f). Therefore, increased expression of CD132 my be responsible for stronger response of RA BM CD3 ${ }^{+} \mathrm{CD}_{4}^{+}$ cells for IL-15 stimulation. 


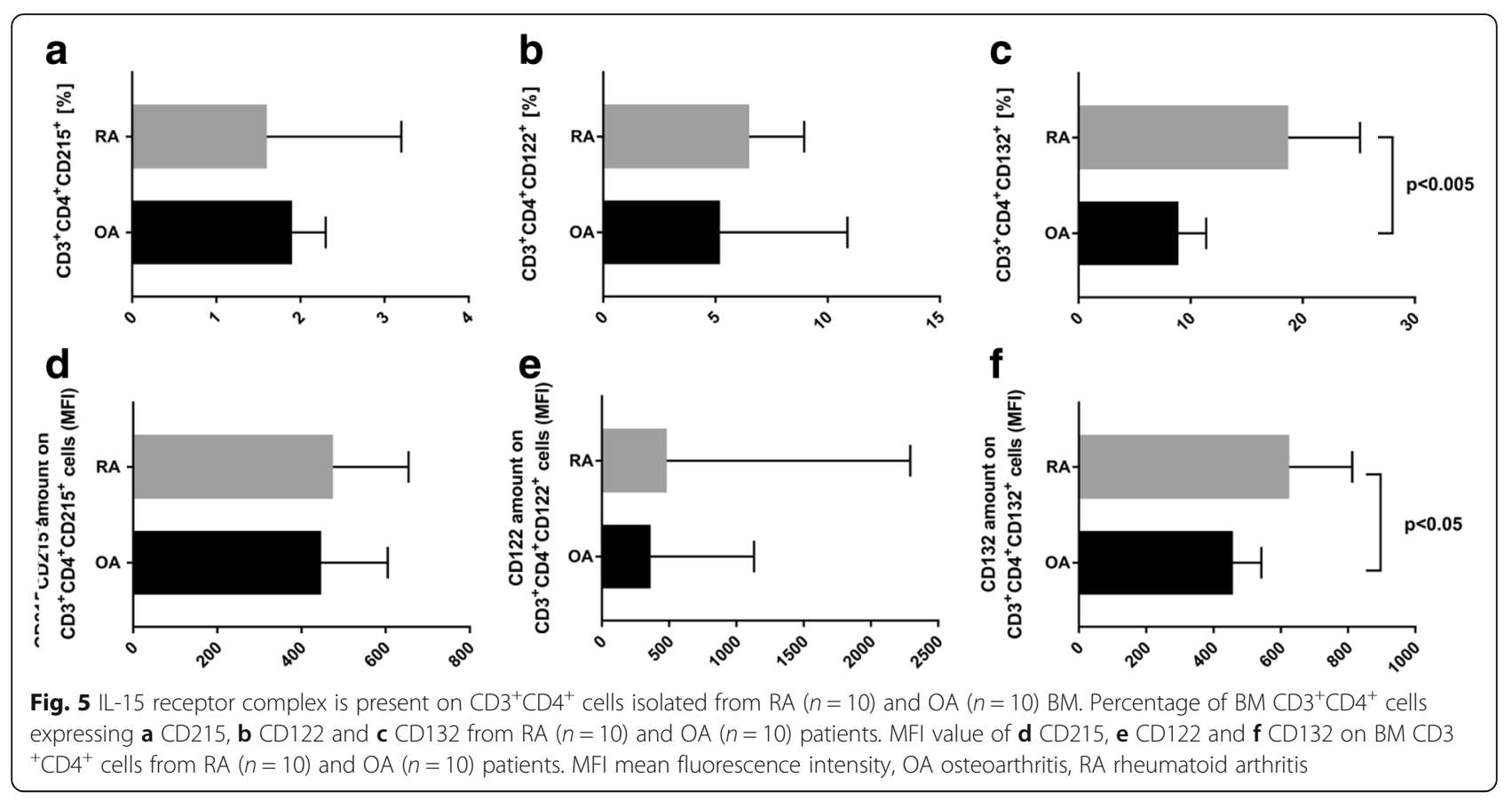

\section{Discussion}

In the recent years, there has been growing evidence supporting implication of the BM compartment in initiation and perpetuation of the inflammatory processes in RA. Elegant studies confirmed that BM oedema, which is often present in RA patients, reflects true BM inflammation [21]. Moreover, numerous studies have reported that BM oedema represents an independent predictor of RA development and radiographic progression in patients with undifferentiated arthritis [22-26]. Such ongoing inflammatory processes in BM are also reflected by the activation of B cells and T cells. As we reported previously, ligation of Toll-like receptors (TLR) triggered BM-derived B-cell activation [3], and the number of recently activated $\mathrm{T}$ cells was significantly elevated in RA BM [2].

Overproduction of several proinflammatory cytokines, including TNF- $\alpha$, IL-1 $\beta$, IL-6, IL-15 and relatively recently added IL-17, contribute to pathological processes in RA [6, 27]. Tissue-specific IL-17 exacerbates tissue damage and disease chronicity. It was shown that expression of IL-17 mRNA and protein are higher in RA joints compared to healthy controls [28]. However, there are no data regarding BM production of $\mathrm{IL}-17$ in the course of RA. In the present study we investigated the Th17 compartment in RA BM. In the first sets of experiments the concentrations of IL-17 dimers in BM were measured. We found a significantly higher concentration of IL-17AF in BM of patients with RA than those with OA (Fig. 1). Moreover, in both patient groups, IL-17AF levels in BM plasma were higher than in peripheral blood plasma. There were no differences in BM IL-17FF levels in the OA and RA patient groups. Nonetheless, the IL-17FF concentration in BM plasma was also increased when compared to blood plasma (in both groups of patients). Thus, our results show that BM represents an important source of both IL-17AF and IL-17FF and that overproduction of IL-17AF seems to be characteristic for RA BM.

IL-17 is an important player in the proinflammatory cytokine network. This cytokine may induce production of various proteins in tissues, but when acting alone its effects are not highly pronounced. In contrast, its interaction with other cytokines such as TNF- $\alpha$, IL-1 $\beta$, IFN- $\gamma$ or IL-22 leads to synergistically increased production of IL-6 and IL-8 [29-31]. IL-17 also contributes to increased osteoclastogenesis: it can directly induce differentiation of osteoclasts from monocytes and is able to up-regulate RANKL synthesis by RA fibroblast-like synoviocytes [32]. As we have reported before [33], the RANKL concentration was elevated in RA BM plasma in comparison to OA BM plasma. Thus, the increased production of IL-17A in RA BM may be associated with bone and cartilage destruction observed in the course of RA.

The optimal conditions for Th17 differentiation are still a highly debated issue. There is general agreement that IL-6 and IL-23 participate in the differentiation and survival of murine Th17 [34]. However, even in the murine model, the role of TGF- $\beta$ remains controversial. For example, there is a study showing that murine, highly pathogenic Th17 lymphocytes differentiate in the absence of TGF- $\beta$ [35]. 
Several cytokines, including IL-1 $\beta$, IL-6, IL-23 and TGF$\beta$, were demonstrated to participate in the differentiation and survival of human Th17 cells. However, it has also been shown that only IL- 6 and IL- $1 \beta$, but not TGF- $\beta$, are essential for Th17 differentiation [36]. On the other hand, in some studies the presence of TGF- $\beta$ is necessary for RORc expression in human CD4 cells [37].

We compared concentrations of IL-1 $\beta$, IL-6, IL-23 and TGF- $\beta$ in BM samples obtained from patients with RA and $\mathrm{OA}$ in order to investigate whether RA BM creates suitable conditions for Th17 lymphocyte differentiation/ survival. We found significantly increased levels of IL-1 $\beta$ and IL- 6 in RA BM (Fig. 3a, b). IL-23 and TGF- $\beta$ were also present in RA and OA BM, although at the comparable levels in both patient groups (Fig. 3c, d). In addition, we observed an increased percentage of Th17 cells in the BM of RA patients compared to the BM of OA patients (Fig. 2), indicating that all necessary cytokines described in the literature required for human Th17 cell differentiation are present in BM in sufficient concentrations to trigger differentiation of Th17 cells. It is likely that levels of TGF- $\beta$ and IL-23, although not different between RA and OA, are sufficient for supporting Th17 cell differentiation while highly elevated levels of IL-1 $\beta$ and IL- 6 may be responsible for the higher number of Th17 cells in RA BM. There are observations that Th1-related and Th2-related cytokines (IFN- $\gamma$, IL-4) suppress differentiation of Th17 cells $[11,12]$. However, in our experiments we did not observe increased levels of these cytokines in RA BM in comparison to OA BM (Fig. 3e, f).

The role of IL-15 in Th17 cell differentiation is not clearly defined. The IL-15 concentration is known to correlate with the concentration of IL-17 in synovial fluid from RA patients [13]. In addition, the contribution of IL-15 to the increased level of IL-17 in the course of collagen-induced arthritis has been also reported [38]. Our research demonstrated increased production of IL-17 in RA BMMC after IL-15 stimulation (Fig. 4a). Interestingly, flow cytometry experiments showed that although IL-15 did not affect the percentage of BM cells producing IL-17 in vitro, it increased the amount of intracellular IL-17 (referred as MFI, Fig. 4). Additionally, we found correlation between concentrations of IL-17AF and IL-15 in RA BM plasma. These results suggest that IL-15 may contribute to the phenotype stabilization and survival of Th17 cells as well as the increased production of IL-17. It is noteworthy that such an effect is not characteristic only for RA, but also for OA. However, BMMC obtained from RA patients reacted to IL-15 slightly better, indicating the increased sensitivity of $\mathrm{T}$ cells from RA BM to IL-15. Our analysis showed the presence of IL-15 receptor complex on $\mathrm{CD}^{+} \mathrm{CD}^{+}$cells isolated from BM. Interestingly, the higher percentage of CD3
${ }^{+} \mathrm{CD}^{+}$cells bearing $\mathrm{CD} 132$ present in $\mathrm{RA}$ BM than in $\mathrm{OA} \mathrm{BM}$ may explain why $\mathrm{CD}^{+} \mathrm{CD}^{+}$cells from RA patients react stronger to IL-15 stimulation. It should, however, be noted that the stimulatory effect of IL-15 on IL-17 production in BMMC culture may result from direct stimulation of Th17 cells or other cells capable of producing cytokines involved in Th17 cell differentiation [39].

Another explanation for increased IL-17AF concentration in BM of RA patients could be the increased migration of Th17 cells into the BM. We reported previously the increased levels of some chemokines in BM of patients with RA that indicate the possibility of impaired cell migration in the course of the disease [4]. However, previously we did not evaluate the concentration of CCL20, the key chemokine regulating Th17 migration. CCL20 recruits Th17 cells and dendritic cells to the inflammatory site [20]. CCL20 is typically expressed at a low basal level, but can be strongly induced by proinflammatory cytokine TNF- $\alpha$ [40]. In the present study we found elevated concentrations of CCL20 as well as TNF- $\alpha$ in RA BM plasma. Highly elevated CCL20 in BM of RA patients may participate in the observed increased percentage of Th17 cells as well as the formation of germinal centres in this tissue as we reported before [2].

\section{Conclusions}

Our results indicate that in the course of RA the BM microenvironment can promote the development of Th17 responses and overproduction of IL-17AF. Our observations support the notion that BM actively participates in pathogenesis of RA.

\section{Abbreviations}

7-AAD: 7-Aminoactinomycin D; Ab: Antibody; APC: Allophycocyanin; APCCy7: Allophycocyanin tandem conjugate with cyanine; BM: Bone marrow; BMMC: Bone marrow mononuclear cells; ELISA: Enzyme-linked immunosorbent assay; FITC: Fluorescein isothiocyanate; IFN-ү: interferon gamma; IL: Interleukin; MFI: Mean fluorescence intensity; $\mathrm{NaN}_{3}$ : Sodium azide; OA: Osteoarthritis; PE: Phycoerythrin; PE-Cy7: Phycoerythrin tandem conjugate with cyanine; PerCp-Cy5.5: Peridinin-chlorophyll proteins tandem conjugate with cyanine; PMA: Phorbol 12-myristate 13-acetate;

RA: Rheumatoid arthritis; TGF- $\beta$ : Transforming growth factor beta;

Th: T-helper; TNF-a: Tumour necrosis factor alpha

\section{Funding}

This work was partially funded by grant number UMO-2011/03/B/NZ6/05035 from National Science Centre, Poland and a core grant to National Institute of Geriatrics, Rheumatology and Rehabilitation from Polish Ministry of Science and Higher Education.

\section{Availability of data and materials}

Files relevant to this work will be shared on request.

\section{Authors' contributions}

EK-W conceived and designed the study, performed flow cytometry experiments, data analysis and data interpretation, and wrote the manuscript. WK participated in manuscript writing and performed ELISA tests. MP-S performed immunohistochemical analysis. TB was responsible for cell isolation and culture. BM-N, IS and RG helped with recruited patients and acquired and analysed clinical data. MP, AR and MM performed ELISA tests. US participated in manuscript writing. WM participated in study design. 
All authors drafted the manuscript, and all authors read and approved the final manuscript. All authors meet authorship requirements according to the International Committee of Medical Journal Editors.

\section{Ethics approval and consent to participate}

All patients enrolled in the study gave informed consent according to the Declaration of Helsinki and the study was approved by the National Institute of Geriatrics, Rheumatology and Rehabilitation Ethics Committee (decision no. 2005/01/20)

\section{Consent for publication}

Not applicable.

\section{Competing interests}

The authors declare that they have no conflicts of interest.

\section{Publisher's Note}

Springer Nature remains neutral with regard to jurisdictional claims in published maps and institutional affiliations.

\section{Author details}

'Department of Pathophysiology and Immunology, National Institute of Geriatrics, Rheumatology and Rehabilitation (NIGRR), Spartanska 1, 02-637 Warsaw, Poland. ${ }^{2}$ Department of Pathology, National Institute of Geriatrics, Rheumatology, and Rehabilitation (NIGRR), Warsaw, Poland. ${ }^{3}$ Department of Diagnostic Hematology, Institute of Hematology and Transfusion Medicine, Warsaw, Poland. ${ }^{4}$ Department of Rheumoorthopaedic Surgery, National Institute of Geriatrics, Rheumatology and Rehabilitation (NIGRR), Warsaw, Poland.

Received: 16 February 2017 Accepted: 21 November 2017

Published online: 08 December 2017

\section{References}

1. Scott DL, Wolfe F, Huizinga TWJ. Rheumatoid arthritis. Lancet. 2010; 376(9746):1094-108

2. Kuca-Warnawin E, Burakowski T, Kurowska W, Prochorec-Sobieszek M, Radzikowska A, Chorazy-Massalska M, Maldyk P, Kontny E, Maslinski W. Elevated number of recently activated T cells in bone marrow of patients with rheumatoid arthritis: a role for interleukin 15? Ann Rheum Dis. 2011; 70(1):227-33.

3. Rudnicka W, Burakowski T, Warnawin E, Jastrzebska M, Bik M, Kontny E, Chorazy-Massalska M, Radzikowska A, Buler M, Maldyk P, et al. Functional TLR9 modulates bone marrow B cells from rheumatoid arthritis patients. Eur J Immunol. 2009;39(5):1211-20.

4. Kuca-Warnawin EH, Kurowska WJ, Radzikowska A, Massalska MA, Burakowski T, Kontny E, Slowinska I, Gasik R, Maslinski W. Different expression of chemokines in rheumatoid arthritis and osteoarthritis bone marrow. Reumatologia. 2016;54(2):51-3.

5. JongenLavrencic M, Peeters HRM, Wognum A, Vreugdenhil G, Breedveld FC, Swaak AJG. Elevated levels of inflammatory cytokines in bone marrow of patients with rheumatoid arthritis and anemia of chronic disease. J Rheumatol. 1997;24(8):1504-9.

6. Papadaki HA, Kritikos HD, Gemetzi C, Koutala H, Marsh JC, Boumpas DT, Eliopoulos GD. Bone marrow progenitor cell reserve and function and stromal cell function are defective in rheumatoid arthritis: evidence for a tumor necrosis factor alpha-mediated effect. Blood. 2002;99(5):1610-9.

7. Beringer $A$, Noack M, Miossec P. IL-17 in chronic inflammation: from discovery to targeting. Trends Mol Med. 2016;22(3):230-41.

8. Wright JF, Guo YJ, Quazi A, Luxenberg DP, Bennett F, Ross JF, Qiu YC, Whitters MJ, Tomkinson KN, Dunussi-Joannopoulos K, et al. Identification of an interleukin 17F/17A heterodimer in activated human CD4+ T cells. J Biol Chem. 2007:282(18):13447-55.

9. Veldhoen M, Hocking RJ, Atkins CJ, Locksley RM, Stockinger B. TGF $\beta$ in the context of an inflammatory cytokine milieu supports de novo differentiation of IL-17-producing T cells. Immunity. 2006;24(2):179-89.

10. Volpe E, Servant N, Zollinger R, Bogiatzi SI, Hupe P, Barillot E, Soumelis V. A critical function for transforming growth factor-beta, interleukin 23 and proinflammatory cytokines in driving and modulating human $\mathrm{T}(\mathrm{H})-17$ responses. Nat Immunol. 2008;9(6):650-7.
11. Park H, Li Z, Yang XO, Chang SH, Nurieva R, Wang YH, Wang Y, Hood L, Zhu Z, Tian $\mathrm{Q}$, et al. A distinct lineage of CD4 T cells regulates tissue inflammation by producing interleukin 17. Nat Immunol. 2005;6(11):1133-41.

12. van Hamburg JP, Mus AM, de Bruijn MJ, de Vogel L, Boon L, Cornelissen F, Asmawidjaja P, Hendriks RW, Lubberts E. GATA-3 protects against severe joint inflammation and bone erosion and reduces differentiation of Th17 cells during experimental arthritis. Arthritis Rheum. 2009;60(3):750-9.

13. Ziolkowska M, Koc A, Luszczykiewicz G, Ksiezopolska-Pietrzak K, Klimczak E, Chwalinska-Sadowska H, Maslinski W. High levels of IL-17 in rheumatoid arthritis patients: IL-15 triggers in vitro IL-17 production via cyclosporin Asensitive mechanism. J Immunol. 2000;164(5):2832-8.

14. Hirota $\mathrm{K}$, Yoshitomi H, Hashimoto M, Maeda S, Teradaira S, Sugimoto N, Yamaguchi T, Nomura T, Ito H, Nakamura T, et al. Preferential recruitment of CCR6-expressing Th17 cells to inflamed joints via CCL20 in rheumatoid arthritis and its animal model. J Exp Med. 2007;204(12):2803-12.

15. Esplugues $E$, Huber $S$, Gagliani N, Hauser AE, Town T, Wan YY, O'Connor Jr W, Rongvaux A, Van Rooijen N, Haberman AM, et al. Control of TH17 cells occurs in the small intestine. Nature. 2011;475(7357):514-8.

16. Altman R, Alarcon G, Appelrouth D, Bloch D, Borenstein D, Brandt K, Brown C, Cooke TD, Daniel W, Feldman D, et al. The American College of Rheumatology criteria for the classification and reporting of osteoarthritis of the hip. Arthritis Rheum. 1991;34:505-14.

17. Arnett FC, Edworthy SM, Bloch DA, McShane DJ, Fries JF, Cooper NS, Healey LA, Kaplan SR, Liang MH, Luthra HS, et al. The American Rheumatism Association 1987 revised criteria for the classification of rheumatoid arthritis. Arthritis Rheum. 1988:31(3):315-24.

18. Kontny E, Grabowska A, Kowalczewski J, Kurowska M, Janicka I, Marcinkiewicz J, Maslinski W. Taurine chloramine inhibition of cell proliferation and cytokine production by rheumatoid arthritis fibroblast-like synoviocytes. Arthritis Rheum. 1999;42(12):2552-60.

19. Wright JF, Guo Y, Quazi A, Luxenberg DP, Bennett F, Ross JF, Qiu Y, Whitters MJ, Tomkinson KN, Dunussi-Joannopoulos K, et al. Identification of an interleukin 17F/17A heterodimer in activated human CD4+ T cells. J Biol Chem. 2007:282(18):13447-55.

20. Chabaud M, Page G, Miossec P. Enhancing effect of IL-1, IL-17, and TNFalpha on macrophage inflammatory protein-3alpha production in rheumatoid arthritis: regulation by soluble receptors and Th2 cytokines. J Immunol. 2001;167(10):6015-20.

21. Jimenez-Boj E, Nobauer-Huhmann I, Hanslik-Schnabel B, Dorotka R, Wanivenhaus AH, Kainberger F, Trattnig S, Axmann R, Tsuji W, Hermann S, et al. Bone erosions and bone marrow edema as defined by magnetic resonance imaging reflect true bone marrow inflammation in rheumatoid arthritis. Arthritis Rheum. 2007:56(4):1118-24.

22. Boyesen P, Haavardsholm EA, Ostergaard M, van der Heijde D, Sesseng S, Kvien TK. MRI in early rheumatoid arthritis: synovitis and bone marrow oedema are independent predictors of subsequent radiographic progression. Ann Rheum Dis. 2011;70(3):428-33.

23. Haavardsholm EA, Boyesen P, Ostergaard M, Schildvold A, Kvien TK. Magnetic resonance imaging findings in 84 patients with early rheumatoid arthritis: bone marrow oedema predicts erosive progression. Ann Rheum Dis. 2008;67(6):794-800

24. Solau-Gervais E, Legrand JL, Cortet B, Duquesnoy B, Flipo RM. Magnetic resonance imaging of the hand for the diagnosis of rheumatoid arthritis in the absence of anti-cyclic citrullinated peptide antibodies: a prospective study. J Rheumatol. 2006;33(9):1760-5.

25. Boutry N, Do Carmo CC, Flipo RM, Cotten A. Early rheumatoid arthritis and its differentiation from other joint abnormalities. Eur J Radiol. 2009; $71(2): 217-24$.

26. Duer-Jensen A, Horslev-Petersen K, Hetland ML, Bak L, Ejbjerg BJ, Hansen MS, Johansen JS, Lindegaard HM, Vinterberg H, Moller JM, et al. Bone edema on magnetic resonance imaging is an independent predictor of rheumatoid arthritis development in patients with early undifferentiated arthritis. Arthritis Rheum. 2011;63(8):2192-202.

27. Jongen-Lavrencic M, Peeters HR, Wognum A, Vreugdenhil G, Breedveld FC, Swaak AJ. Elevated levels of inflammatory cytokines in bone marrow of patients with rheumatoid arthritis and anemia of chronic disease. J Rheumatol. 1997;24(8):1504-9.

28. Shahrara S, Huang Q, Mandelin AM, Pope RM. TH-17 cells in rheumatoid arthritis Arthritis Research \& Ther. 2008;10(4):R93.

29. Onishi RM, Gaffen SL. Interleukin-17 and its target genes: mechanisms of interleukin-17 function in disease. Immunology. 2010;129(3):311-21. 
30. Chabaud M, Fossiez F, Taupin JL, Miossec P. Enhancing effect of IL-17 on IL1-induced IL-6 and leukemia inhibitory factor production by rheumatoid arthritis synoviocytes and its regulation by Th2 cytokines. J Immunol. 1998; 161(1):409-14.

31. Zrioual $S$, Ecochard $R$, Tournadre A, Lenief $V$, Cazalis MA, Miossec $P$. Genome-wide comparison between IL-17A- and IL-17F-induced effects in human rheumatoid arthritis synoviocytes. J Immunol. 2009;182(5):3112-20.

32. Kim KW, Kim HR, Kim BM, Cho ML, Lee SH. Th17 cytokines regulate osteoclastogenesis in rheumatoid arthritis. Am J Pathol. 2015;185(11):3011-24.

33. Radzikowska ABT, Maldyk P, Michalak C, Jung L, Maslinski W. Soluble and cell-surfac expressed RANKL and osteoprotegerin in bone marrow from rheumatoid aerhritis patients. Ann Rheum Dis. 2007;66:267.

34. Kimura A, Kishimoto T. IL-6: regulator of Treg/Th17 balance. Eur J Immunol. 2010;40(7):1830-5.

35. Ghoreschi K, Laurence A, Yang XP, Tato CM, McGeachy MJ, Konkel JE, Ramos HL, Wei L, Davidson TS, Bouladoux N, et al. Generation of pathogenic $T(H) 17$ cells in the absence of TGF-beta signalling. Nature. 2010; 467(7318):967-71.

36. Acosta-Rodriguez EV, Napolitani G, Lanzavecchia A, Sallusto F. Interleukins 1 beta and 6 but not transforming growth factor-beta are essential for the differentiation of interleukin 17-producing human Thelper cells. Nat Immunol. 2007:8(9):942-9.

37. Burgler S, Ouaked N, Bassin C, Basinski TM, Mantel PY, Siegmund K, Meyer $\mathrm{N}$, Akdis CA, Schmidt-Weber CB. Differentiation and functional analysis of human T(H)17 cells. J Allergy Clin Immunol. 2009;123(3):588-95. 595 e581-7.

38. Yoshihara K, Yamada H, Hori A, Yajima T, Kubo C, Yoshikai Y. IL-15 exacerbates collagen-induced arthritis with an enhanced CD4+ T cell response to produce IL-17. Eur J Immunol. 2007;37(10):2744-52.

39. Harris K, Fasano A, Mann D. Monocytes differentiated with IL-15 support Th17 and Th1 responses to wheat gliadin: implications for celiac disease. Clin Immunol. 2010;135(3):430-9.

40. Schutyser E, Struyf S, Van Damme J. The CC chemokine CCL20 and its receptor CCR6. Cytokine Growth Factor Rev. 2003;14(5):409-26.

\section{Submit your next manuscript to BioMed Central and we will help you at every step:}

- We accept pre-submission inquiries

- Our selector tool helps you to find the most relevant journal

- We provide round the clock customer support

- Convenient online submission

- Thorough peer review

- Inclusion in PubMed and all major indexing services

- Maximum visibility for your research

Submit your manuscript at www.biomedcentral.com/submit
Biomed Central 